\title{
Dynamic experimental internationalization: Strategy of SMEs from a transition economy
}

\author{
Mai Thi Thanh Thai • Li Choy Chong
}

Published online: 18 August 2013

(C) Springer Science+Business Media New York 2013

\begin{abstract}
This paper presents a model of dynamic experimental internationalization which we developed by employing Straussian Grounded Theory to explain how and why small- and medium-sized enterprises in a transitional economy (Vietnam) internationalize. Unlike other knowledge-based internationalization models, our model proposes that the internationalization process of these firms is largely influenced by their current experience rather than past experience because of frequent shifts in the institutional environment. Moreover, this process is directed not only by organizational goals but also critically by managerial goals. As such, these firms internationalize by continuously conducting multiple experiments to find strategies that optimize their chances of meeting these goals by ensuring the best fit with their current environment and thereby also quick responses to environment changes.
\end{abstract}

Keywords Internationalization process $\cdot$ Knowledge-based internationalization model · SME · Transition economy · Vietnam · Grounded Theory

\section{Introduction}

It is widely acknowledged that current theories of the internationalization of firms are not suitable for explaining the internationalization of small and medium enterprises (SMEs) based in countries characterized by distorted information, weak market structures, poorly specified property rights, and changing institutional environment (Nee 1992; Peng and Heath 1996; Peng 2000; Pisani 2009; etc.). Most studies of the internationalization process have focused on firms from developed economies (Canabala and White III 2008) with a strong bias towards North America, Western Europe, and Japan (Werner

\footnotetext{
M. T. T. Thai $(\bowtie)$

Department of International Business, HEC Montréal, 3000, chemin de la Côte-Sainte-Catherine, Montréal, QC H3T 2A7, Canada

e-mail: email@maithai.org

L. C. Chong $(\bowtie)$

International Management (South East Asia), Asia Research Centre, University of St. Gallen, Tigerbergstrasse 9, CH-9000 St. Gallen, Switzerland e-mail: li-choy.chong@unisg.ch
} 
2002). They assume that (1) internationalizing firms have good knowledge of their domestic markets and (2) their internationalization strategy involves exploiting foreign opportunities and overcoming possible liabilities of foreignness by their capacity for using their resources and accumulating international market knowledge (Dunning 2001; Barney et al. 2001; Peng 2001; Johanson and Vahlne 2009; Buckley and Casson 2009; Benito et al. 2009; etc.). Furthermore, Brouthers and Hennart (2007, p. 417) found that "almost all models of international market entry assume that managers are free to choose the most efficient entry mode." These assumptions do not hold in most developing and transition countries, in which the business environment changes quickly and frequently, and particularly in countries in which information is censored by the government. Furthermore, SMEs in these countries not only have to cope with the well-known problems typically encountered by SMEs (e.g., lack of managerial and marketing skills, lack of financial resources, and so on; see Huang and Brown 1999 for a full list) but also are further constrained by external and internal factors arising from the institutional development effort. As a result, analysis of the variables pertaining to these countries is becoming an important component of our understanding of the globalization of business (Ruzzier et al. 2006; Pisani 2009).

By using Straussian grounded-theory method, our study proposes a model of dynamic experimental internationalization that is able to explain how and why Vietnamese SMEs internationalize. This model extends the explanatory power of the behavioral school of thought and advances knowledge-based internationalization models. This paper describes our research process from literature review, methodology selection and implementation, to insights of the findings from our research. After presenting our empirically based theoretical model, we highlight this study's contribution to theory, managerial implications, and limitations.

\section{Literature review}

Knowledge-based internationalization literature

Welch and Paavilainen-Mäntymäki's literature review on the internationalization of the firm (2013) highlights a serious lack of research on how firms internationalize while most studies focus on determinants, i.e., the "what" question. Within the limited body of literature on how firms internationalize, prior research on firms based in transition economies is very scanty. As such, the knowledge of how SMEs in transition economies internationalize is still in the blackbox. Therefore, we did an extensive review of all existing internationalization theories to develop the theoretical foundation for this study (Appendix). We found that the behavioral theories offer promising prospectives because their basic assumptions can be applied in the context of transition economies, and this literature allows us to examine the impact of contingent factors.

Papadopoulos's study (1988) reveals that the majority of SMEs do not analyze the market systematically before internationalizing. At these firms, managerial work is fragmentary and subject to bounded rationality (Bjorkman and Forsgren 2000). In transition economies, SMEs have to face a changing environment both at home and abroad so they must craft their internationalization strategies as they acquire new knowledge. For these firms, doing business abroad is like taking cautious steps into unknown territory rather 
than the result of a rational choice based on economic analyses because the difference between conducting business in the home country and abroad can be analyzed largely in terms of the level of knowledge within the firm itself (Masurel and Smit 2000). Therefore, the most relevant literature is on knowledge-based internationalization. In this section, we present this literature in chronological order of its development (the Uppsala models, innovation-related models, network models, and international entrepreneurship models) and discuss potentials to advance this knowledge with a study of SMEs based in transition economies.

\section{Uppsala models}

The first Uppsala model is the S model (Johanson and Wiedersheim-Paul 1975) which posits that firms first develop in their domestic markets and then follow a series of incremental decisions in their internationalization process since the most important obstacles to internationalization - lack of knowledge and resources - can be reduced by means of a gradual process of learning and decisions related to foreign markets and operations. Its successor known as the international process model (IP model) posits that the internationalization process is a self-reinforcing cycle of knowledge acquisition, risk reduction, and increased market commitment (Johanson and Vahlne 1977a, b). As a result, internationalization often proceeds slowly and incrementally. Both of these models have been supported by several empirical research studies on the early stages of the internationalization (mostly the export phase) of firms from developed countries (e.g., Davidson 1983; Hook Jr. and Czinkota 1988; Fina and Rugman 1996; etc.). However, many studies of internationalization processes involving multiple modes of operation (e.g., Lau 1992; Zafarullah et al. 1998; etc.) as well as studies on international new ventures, particularly firms from economies in transition (e.g., Oviatt and McDougall 1997; Lau 2003; Thai and Chong 2008; Manolovaa et al. 2010), give strong evidences showing that these firms do not internationalize the way predicted by these models.

\section{Innovation-related models}

Innovation-related models (Bilkey and Tesar 1977a, b; Cavusgil 1990; Reid 1981; Hadjikhani et al. 2013) consider the internationalization process to unroll as an innovation process in which firms will go through various incremental stages from preinvolvement to full involvement. Though having some support in the literature, these models are criticized for their limited explanation power. First, viewing exporting as an innovation is unusual in that the idea is not totally foreign to the average businessman and is an intangible idea rather than an object (Lee and Brasch 1978). Second, the models have huge numbers of variables and are composed mainly of non-observable concepts so that it is difficult to delimit stages (Andersen 1993). Third, the models do not take into account of today's improved communication and transportation along with the homogenization of markets that may cause firms to either skip stages or not to follow through on stages (Oviatt and McDougall 1994). Fourth, their empirical studies have been limited to cross-sectional methodology, which precludes studies of the movement of an individual firm from stage to stage. 
Johanson and Mattsson (1993a, b) posit that the internationalization characteristics of the firm and of the market influence the internationalization process. The early starter does not know much about foreign markets, and it cannot count upon utilizing relationships in the domestic market to learn about foreign markets, so it begins internationalization in nearby markets, using agents rather than subsidiaries. The lonely starter has more experience in relationships with and in foreign countries than other firms in its production net and thus may function as a bridge to promote internationalization among other firms. If the market is highly internationalized, the late starter enjoys indirect relationships with foreign networks and can be pulled out to internationalize. Its international extension pattern is, therefore, configured by the relations. A critical problem with this model is that it offers imprecise conclusions about the manifestations of internationalization (Bjorkman and Forsgren 2000). Consequently, it can only help us to understand market behavior in general, but it cannot give a specific answer to the research question of how firms internationalize. Nevertheless, it reveals that firms may pursue regular/incremental approach in one market but irregular/non-incremental in another depending on the host countries' internationalization degree.

\section{Network models}

Johanson and Vahlne (2009) put forth the network internationalization process model whose basic structure is similar to the IP model but is driven by different mechanisms. In this model, the mechanisms of state are the recognition of knowledge, opportunities, and position, while the mechanisms to change are relationships. It emphasizes that the performance of current activities is explicitly presented as learning, creating, and trust building. The gist of this model is that "internationalization is the outcome of a firm's actions to strengthen network positions by what is traditionally referred to as improving or protecting their position in the market" (Johanson and Vahlne 2009, p. 1423) and the focus of multinational firms is moving "from structure of production to change processes in business relations and entrepreneurship" (Vahlne and Johanson 2013, p. 189). This network model, therefore, assumes that the decision makers are conscious of the market structure in which the firm is positioned and have strong managerial capabilities.

This is not always applicable to SMEs because their managers often lack managerial and marketing skills (Huang and Brown 1999), and Vietnamese SMEs have to cope with distorted information, weak market structure, and in many cases poor information and communication technology infrastructure. Secondly, the model assumes that defending or improving the firm's position is their goal. This is not the case for state-owned enterprises and state-controlled enterprises which are the dominant forms of Vietnamese businesses and whose stakeholders' interests are not necessarily in the firm's financial performance or the improvement of the firms' position. Thirdly, the model implies internationalization is not a one-way road with which it grows in a consistent direction to enhance the firm's network position. Benito and Welch (1997) argue very well that firms de-internationalize for various reasons ranging from poor performance of particular foreign operations to adverse governmental action and the inability to fulfill the expected benefits of diversification moves, acquisitions, and cooperative ventures. Fourthly, the assumption that stakeholders at all levels share common goals is not realistic (Aharoni et al. 2011). 


\section{International entrepreneurship models}

Wright et al. (2007) argue for using an international entrepreneurship perspective as a counterpoint to the established internationalization perspectives for a better understanding of the aspirations and needs of SMEs. Jones and Coviello (2005) propose that internationalization is an entrepreneurial process that occurs as value-creating events as a result of learning from behavior and performance. In a similar light, Andersson (2011) argues that internationalization resembles entrepreneurship and that its process is similar to the effectuation process in terms of environment characteristics, a limited number of available options, incremental development, and an emphasis on cooperative strategies. A critique on these entrepreneurship models is that they do not explain the behavior of firms whose management are not owners of the firm. In Vietnam, however, the majority of firms are state-owned enterprises (SOEs) and/or recently privatized SOEs in which the management are appointed by the State and are not necessarily entrepreneurial.

\section{Knowledge-based model}

Mejri and Umemoto's model of SME internationalization (2010) posits that firms' internationalization is determined by market knowledge, experiential knowledge, network knowledge, cultural knowledge, and entrepreneurial knowledge. The model shows that firms develop incrementally through the pre-internationalization phase, then the noviceinternationalizing phase, and then the experienced internationalizing phase. This model suggests that the international development of a firm depends on the knowledge accumulated throughout the course of its history. In the fast changing environment of transition economies, it is uncertain if past knowledge is useful in the new reality. Furthermore, the model does not account for knowledge of the home country's institutional environment and so its applicability in the context of transition economy is limited.

General critique of the knowledge-based internationalization literature

All of the models in the knowledge-based internationalization literature imply that companies must be successful with weaker commitments in terms of their foreign operating mode (such as exporting) before they are willing to make higher commitments (such as direct foreign investment). Companies act this way because "rational" firms seek to avoid uncertainty (i.e., the entrepreneur's confidence in his estimates or expectations) and risks (i.e., the possible outcomes of action); they specifically seek to avoid the loss that might be incurred if a given action is taken (Penrose 1959).

However, Chen et al. (2001) found that firms from economies in transition do make stronger commitments because of failure with weaker commitments. Since a firm is a loosely coupled administrative organization whose structure is the creation of the people who run it (Penrose 1959), its different actors, such as investors and managers at different levels, have different interests and ideas concerning its development (Aharoni 1966). This explains why business decision makers may deviate from profitmaximizing behaviors (Tirole 1988). As a result, a firm's success or failure with a certain internationalization strategy may not determine the continuation, modification, or discontinuation of a strategy. 
On the other hand, while the firm's current activities may be shaped largely by conscious attempts to achieve a "rational" organization, it may develop rather haphazardly in response to immediate needs (Penrose 1959). The firm is constrained by the uncertainty of its environment, the problems of maintaining a viable coalition, and the limitations on its capacity as a system for assembling, storing, and using information. As a result, the firm acts as an adaptively rational system rather than an omnisciently rational one and learns from its experience (Cyert and March 1992). In Vietnam, the environment is constantly changing because the countries are looking for and trying alternative ways to move away from a socialist centralized government system. Its transition occurs by rapid, discontinuous change in large steps, information about which is often unavailable to the general public until the steps have already been taken. The resulting structural changes can introduce internationalization shocks (such as new policies that open/restrict access to certain foreign markets, international agreements that alter the psychic distance to certain foreign markets, etc.). This factor is not accounted for in these models. Furthermore, knowing that information is limited and may be distorted by government propaganda, decision makers in these countries' firms may not make any commitment decisions when they supposedly see opportunities.

Another weakness of existing models in explaining how and why Vietnamese SMEs internationalize is that they do not address the specific characteristics of these firms which need to acquire multi-layer knowledge, such as general management knowledge, market-specific knowledge, and knowledge about how the direction of institutional changes. These models do not account for the inherently changing institutional environment where frequent and unpredictable institutional changes lead to structural changes in the market. These changes force firms to learn anew and adapt quickly to the new contextual realities and thereby causing the prevailing logic to become obsolete. It is, therefore, not surprising to observe that Vietnamese SMEs internationalize in ways that are inconsistent with the predictions of existing models.

\section{Method}

\section{Research strategy}

Given the scarcity of research in this area and since the material gleaned from earlier studies is unsatisfactory for our purposes, we were somewhat in the dark as to the number of relevant categories and variables needed to address our research question about the internationalization practices of SMEs in transition countries. This situation called for a research methodology that allowed for the development of conceptual categories and their relationships from raw data (Patton 2002). We found that Grounded Theory was the most appropriate for this research. Firstly, Grounded Theory is particularly suitable when "the topic of interest has been relatively ignored in the literature or has been given only superficial attention" (Goulding 2002, p. 55). Secondly, Grounded Theory allows researchers to generate theories that "(1) enable an explanation of behavior, (2) are useful in advancing a theory, (3) are applicable in practice, (4) provide a perspective on behavior, (5) guide and provide a style for research on particular areas of behavior, and (6) provide clear enough categories and hypotheses that crucial ones can be verified in present and future research" (Goulding 2002, p. 43). 
Of the two grounded-theory approaches, we consider Straussian Grounded Theory to be more suitable than Glaserian approach because Straussian Grounded Theory permits a preliminary literature review to identify research problems and areas in which to look for data. For this reason, we employed this method and followed Straussian guidelines on sampling and analysis procedures.

\section{Research setting}

We found Vietnam to be an excellent setting for studying and extending the limits of existing theories for several reasons. First, the degree of internationalization of the Vietnamese economy has been steadily increasing. Its exports have grown much faster than its GDP, to the point where they are among the highest in the dynamic East Asian region and also the world (UNCTAD 2006). The total value of exports and imports in 2007 was more than ten times higher than in 1986 when Vietnam started to implement its opendoor policy. Its import and export indices indicate steady and rapid growth over the past two decades (UNCTAD 2006; GSO 2007). Its institutional environment also changes quickly and frequently (Vo 2004; EIU 2009). The government has devoted considerable effort to encourage Vietnamese businesses to enter the international market and accept competition while maintaining that Vietnam is a socialist-oriented country (M nh 2008). Unlike in developed markets, managers in this country face serious shortages of key information about products, markets, technologies, trends, and so on simply because up-to-date, highquality information sources are rare in Vietnam, and their ability to search for information is restricted by many barriers such as the government's strong information censorship measures (Cheng 2009; ONI 2007), a weak legal system, a complex and opaque bureaucracy, pandemic corruption, a lack of access to investment capital, ineffective associations and poor business services, an inadequate education system, limited access to effective information channels, and so on (Thai 2008). Since Vietnamese SMEs account for over $99 \%$ of all business establishments and respectively 80.6 and $84.2 \%$ of the total number of enterprises participating in import-export activities in Vietnam (ASMED 2006), they are particularly important players in Vietnam's internationalization process.

\section{Selected cases}

Since our research was focused on discovery rather than hypothesis testing (Denscombe 1998), our sampling relied on the principles of theoretical sampling as defined by Strauss and Corbin (1998). For a pilot study at the outset of the sampling process, it was important to select a medium-sized firm that had a strong international presence and which engaged in many operation modes to facilitate the building of the initial theoretical framework. Of the possible candidates, we chose the pilot case study for reasons of convenience, access, and geographic proximity (Yin 2003). After the pilot case had been analyzed, subsequent cases were selected on the basis of the results of the analyses of the previous cases. For example, analysis of $\mathrm{C} 1$ led us hypothesize that demand factors influence the firm's internationalization timing. To validate this proposition, we analyzed two more firms which had begun internationalization at around the same time and operated in the same industry (to ensure that the external conditions were the same) even though one of them (C2) internationalized immediately while the other (C3) internationalized 10 years after its creation. 
We did not try to control variables or look for population representativeness or distribution. Rather, we looked for how concepts varied dimensionally along their properties. In other words, new evidence found at each stage was used to modify or confirm the emerging theory, which then pointed to an appropriate choice of instances in the next phase (Denscombe 1998). We continued to add more cases until the theoretical saturation point was attained (Glaser and Strauss 1967; Tashakkori and Teddlie 1998; Yin 2003). The sampling stopped after 35 cases, when no new evidence able to inform or underpin the development of theoretical points of the emerging theory could be found (Table 1).

During our case selection and analysis, we found that our unit of analysis cannot be the firm as registered with the government; but rather, a network of firms controlled by the same management. Vietnamese firms do not declare their real size since they wish to remain inconspicuous, fearing that if they looked big, they would attract too much attention from both competitors and the government: They would be scrutinized more closely, forced to pay higher taxes, be hounded more by corrupt officials and could be forced to become more socially responsible. This being the case, they would make their firms appear as small as possible on record. The most commonly used tactic is to divide the firm and register its divisions as different enterprises, which although legally independent, are in fact managed as a single firm by the same management. Since our research question focuses on SMEs, every effort was made to ensure that each network of firms studied qualified as an SME in terms of size determined by the Vietnamese government (i.e., having registered capital not exceeding VND 10 billion or approximately US\$622,000, and/or an annual workforce not exceeding 300 people, depending on the industry). As it was not possible to know the real size of a firm until we had studied it, the number of interviewed firms was much higher than the 35 cases here because we had to exclude many firms from the analysis after discovering their real size.

The firms selected for our study are from various Vietnamese provinces, with the number selected from each province varying according the province's contribution to Vietnam's international trade volume. They constitute a balanced representation of business types, ownership forms (private or state-owned), internationalization timing (traditional vs. born-global), operational modes, and market presence.

\section{Data}

The most important data source for this project was qualitative, in-depth, semistructured interviews. In comparison with other sources, they provided richer and deeper insights into the complex phenomena under investigation by answering the why and how research questions (Easterby-Smith et al. 1994; Eisenhardt 1989b; Perren and Ram 2004; Yin 2003). Our informants were managers who were deeply involved with key decision-making processes in their respective firms with regard to developing and implementing their internationalization strategies. Each informant was interviewed twice (an average of $2.5 \mathrm{~h}$ the first time, and $1 \mathrm{~h}$ a year later) over the course of 18 months, from October 2005 to March 2007. In the first round of interviews, we asked the informants questions that had been sent to them a month in advance and questions that arose out of our conversations with them and the analysis of previous cases. In the second round of interviews, we presented our model and asked them whether it correctly depicted their internationalization process. The 


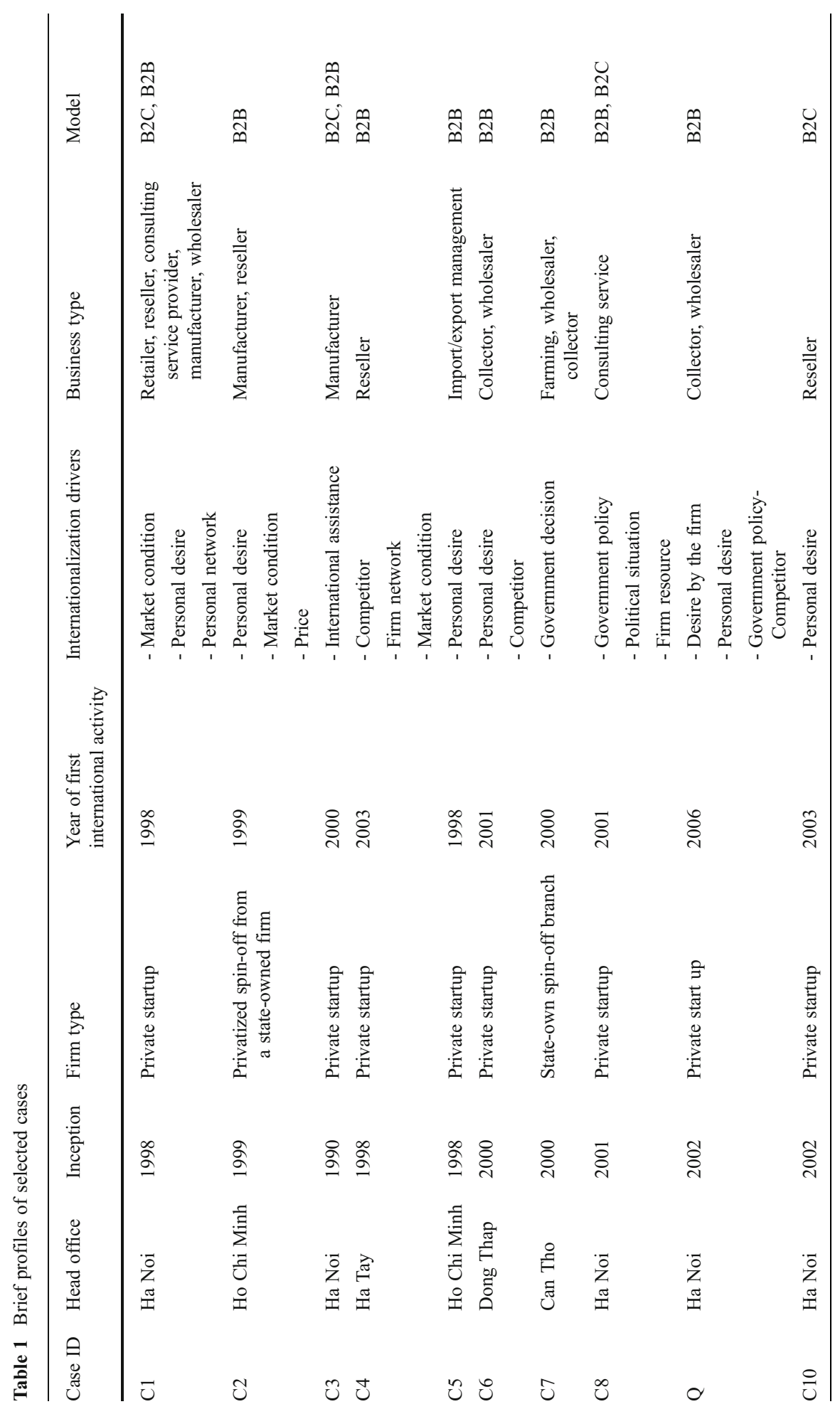




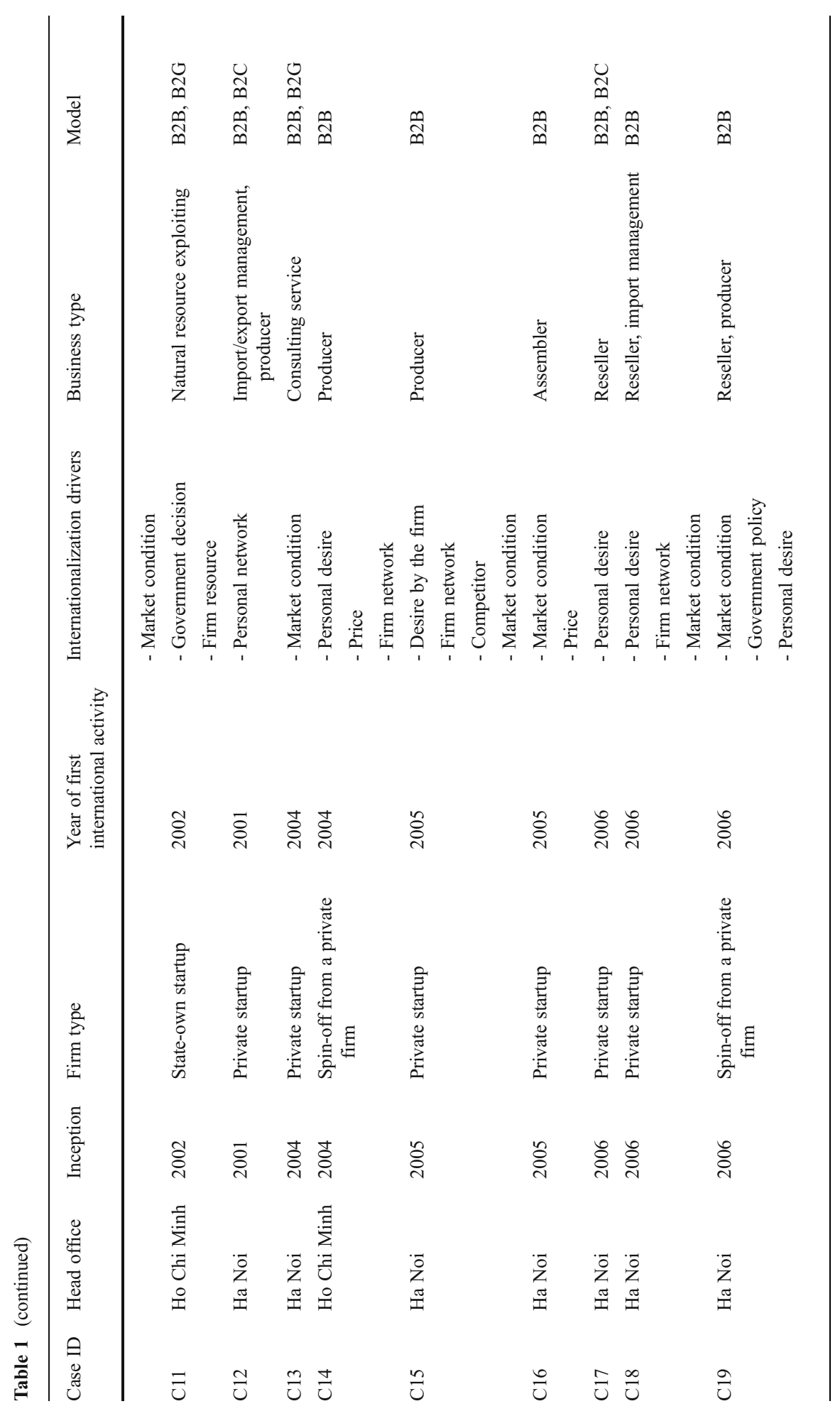




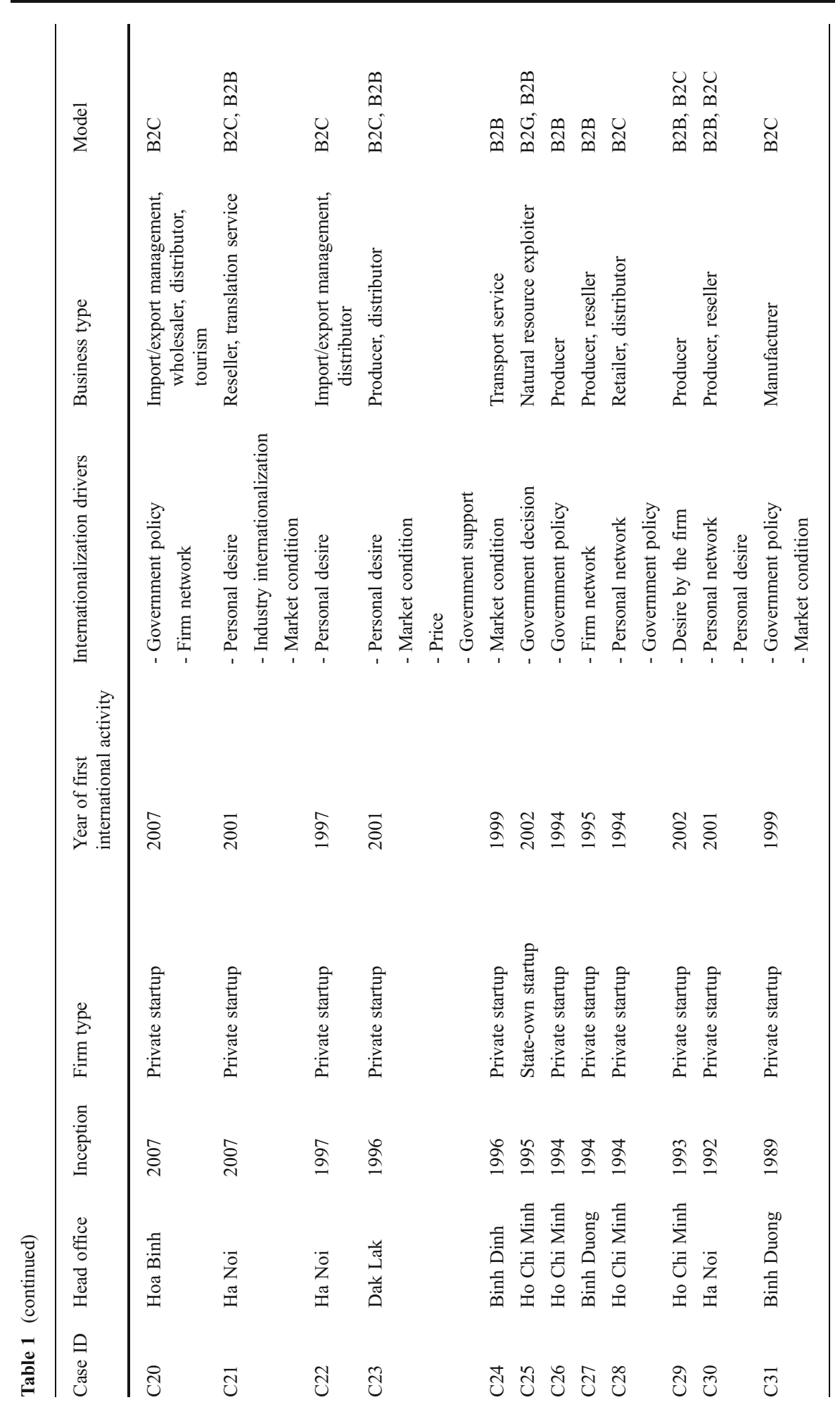




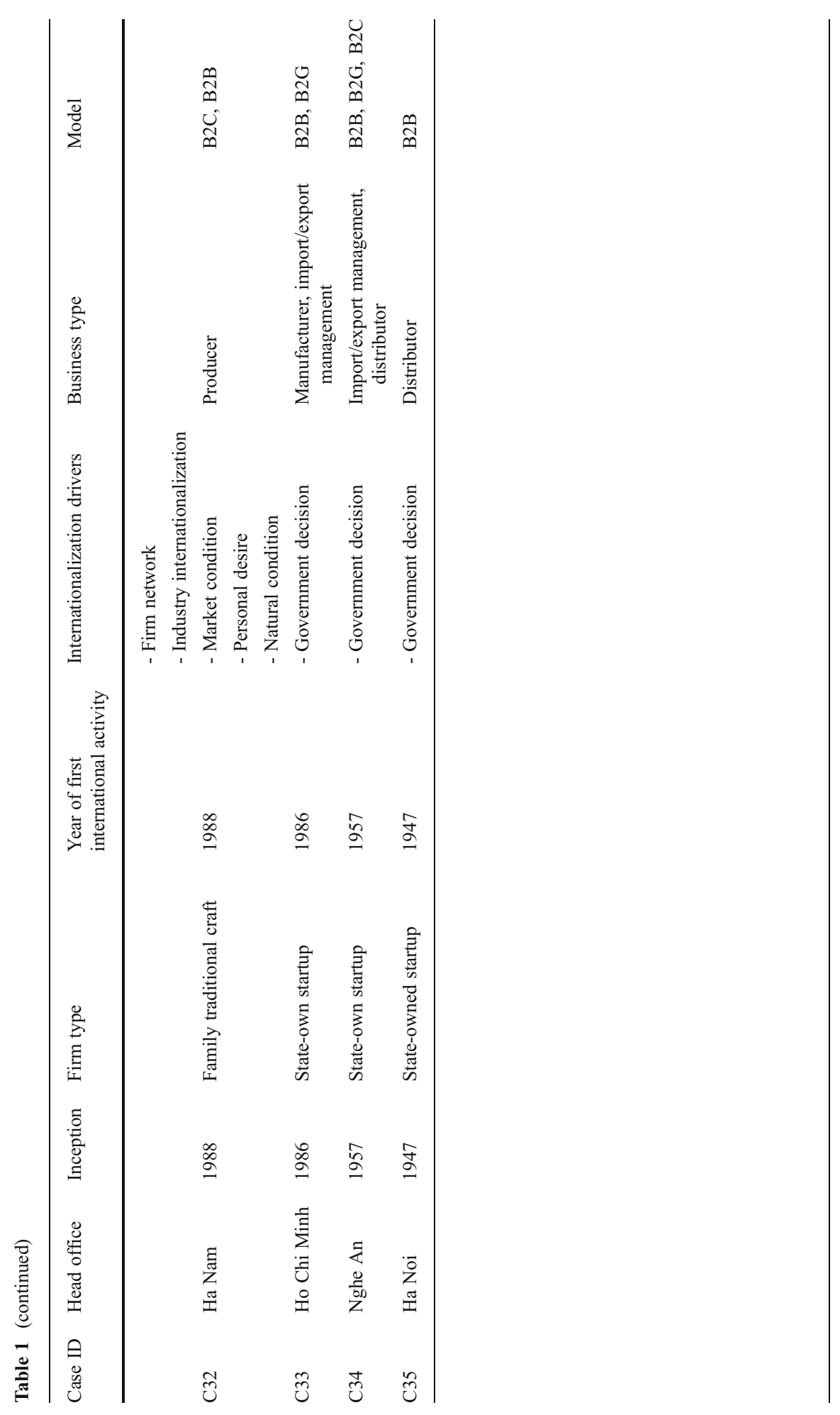


goal of the second round of interview was to get their feedback on the model so we could refine it and eventually validate our findings.

Opportunity recognition and strategy development are dependent on managerial perception and cognition, which, in turn, are dependent on information acquired. Since information in Vietnam, as in other countries in transition, is subject to strong censorship, it was necessary to check if the information available to our informants was distorted and if they had overlooked anything important. Unlike our informants, we had access to both Vietnamese sources and international sources. As a result, we analyzed local and international newspapers, statistical reports by the World Bank, the United Nations, and Vietnam's General Statistics Office, and industry reports available through Datamonitor and Factiva. Doing so gave us a better understanding of the environment in which these firms operated and enable us to evaluate the accuracy of decision makers' perceptions of their market conditions, industry structures, and business environment in Vietnam as well as in their host countries. Comparing the public knowledge against the knowledge that the respondents had acquired for their decision making was an important requirement for understanding the causal factors in theory building.

\section{Analysis}

MAXQDA, a text analysis software program, was used to process the large volume of collected data and to store and retrieve information for analysis. Our coding procedures - open coding, axial coding, and selective coding - were done directly from Vietnamese texts since the language spoken in the interviews was Vietnamese. Doing so avoided "lost-in-translation" problems and enhanced the accuracy of our interpretation. We coded the texts line by line, and the software helped us to build a code hierarchy (which gives answers to the "what," "who," "where," and "when" questions) and a code relation system (which indicates whether any two codes have a relationship and helps to provide answers to the "how" and "why" questions). Throughout our iterating coding processes, we made constant comparison between the data and the theories presented in Table 1 and also between new data and old data. This constant comparison allowed us to identify when we reached theoretical saturation point of the analysis. Since we also categorized the data from each firm by internationalization strategy, we were able to build a process code book to portray the internationalization pattern of the sampled firms and the factors influencing the process.

\section{Findings}

"How we internationalize is like how a tree root finds its paths. Yes, it's all in the dark [i.e., lacking transparent information and direction] so we have to do a lot of guessing. If we hit rocks, we go around them or try another path. When the rock is removed somehow, the root will thrive in that place naturally. If the nutrients in a particular place dry up, we will abandon the root there and live off another root." (Director of C9)

The quote above illustrates the dynamic nature of the internationalization process of the SMEs in our study. Their internationalization pattern is not predetermined. Rather, it is a result of a continual experimentation process. This reliance on emergent 
strategies rather than on planned strategies can be explained by the three factors explained below.

\section{Motivation to internationalize}

Lack of access to quality information due to censorship, propaganda, and weak infrastructure leads people to blame failures on bad luck and to attribute successes to good luck. This makes it possible for managers to use their companies as vehicles to satisfy their personal interests. Therefore, managers play a critical role in their firms' internationalization. Consistent with findings by Praag and Ophem (1995) about entrepreneurship, desirability is the overriding determinant of internationalization. If the willingness factor is absent, this entrepreneurial activity will not take place even in the presence of several pull and push factors cited in the literature as critical to driving SME internationalization (see Etemad (2004) for the full list).

There can be a number of reasons for managers to remain aloof. Key decision makers may fear uncertainty and failure, which can damage their reputation and economic remuneration or even financial security. Indeed, a firm with the capacity to internationalize may not internationalize even when there are opportunities or pressures to do so. Furthermore, state-owned enterprises are reluctant to internationalize without an order from the government because people working for these firms are typically motivated by job security. However, seeing the success of peers can change the opinion of these entrepreneurs:

"My friends and fellow entrepreneurs advised me to sell abroad but I was afraid that I would fail and put everyone at risk. Our company is a family business. My own family and relatives depend on it. I could risk my money but I wouldn't risk the livelihood of my family members.... I could not judge the chance of success all by myself since I was never sure about the accuracy of foreign market information. So the best thing was to see someone doing it first and then we follow suit. You know that the Vietnamese have this proverb "trăm nghe không bă ng môt thấy" [literally translated as: seeing it with your own eye once is better than hearing about it hundreds of times]?" (Owner of C4)

"We could have internationalized much earlier when I started this position. However, our company was a state-owned enterprise at the time and so it was quite rigid. No one wanted to change a running system because everyone liked to be in the comfort zone and risks were not welcomed. From my experience as head of an export department of another company prior to joining our company, I was so sure then that internationalization would help accelerate our company's growth and significantly increase our profit margins. You see how successful we have become since we started internationalizing? When I came, our company had all the necessary conditions for this strategic change. However, I did not do it until I had proven my abilities in running the old system and rallied enough support. I could have lost my job otherwise if anything went wrong." (CEO of C2)

In other cases, managers may also sense that leading their firm to internationalization would force them to compromise certain personal advantages, such as having a 
position with lucrative "fringe" benefits. In these cases, managers would try to avoid internationalization as much as they can.

"Do you think I am stupid enough to let go of my chair? If this firm opened a factory in Laos, I would have to be sent there. By the time I got back, all the meat [fringe benefits] would be gone from the party." (Export manager of C29)

It should be noted that Vietnam perceived to be among the most corrupt in the world (Transparency International 2010). Furthermore, poor information and communication technology infrastructures, unstable institutions, and censorship in Vietnam make it hard for SMEs to get good quality information. As a result, it was possible for mangers to use their firms as vehicles to satisfy their private interests.

As predicted by agency theory (Eisenhardt 1989a), managers' personal goals play a very important role in their firm's internationalization process. When, for example, managers seek the social esteem associated with managing an international firm or an opportunity to live abroad so that their children can get a better education, they push their firm to internationalize even though they know that the firm may not benefit and may even suffer losses. This situation occurs more often in state-owned enterprises (SOEs) that are heavily subsidized by the government. Indeed, it is not rare to read stories in the mass media about SOEs continuing to receive government support despite their poor performance.

"I wanted to send my daughter to a school abroad because our education system is too weak but she was just too young to live alone. So I persuaded my boss to open a branch office in Paris." (Marketing manager of C32)

Despite the presence of personal interests, managers could and do work towards improving their firms on one or several dimensions, such as market share, network position, organizational knowledge, and financial performance. In these cases, firms internationalize for reasons well documented in the internationalization literature (see Etemad 2004).

Given the managers' personal goals in the firm's strategy and development, the firm may internationalize or de-internationalize depending on managerial desire. Even when there is no change in the management structure, the managers' personal goals can change as their life circumstances change (e.g., marriage, children attending university, etc.). In other words, internationalization must be a dynamic process, the pace and extent of which are contingent on the frequency of organizational changes and managers' life changes.

\section{Dynamic perception of the external environment}

Since information is controlled by the state, most SMEs (especially those without connections to the government) would find it hard to access quality information. They do not consider formal information channels (government reports, industry publications, etc.) to be good sources for quality up-to-date information because they suspect them of being propaganda. They rely more on information gained in informal conversations over lunch or dinner, for example, with partners in their business network. As such, they typically make decisions based on intuition, with input from observations, references, and trial-and-error. The managers we interviewed stressed that they had to make decisions based on their feeling and that their feeling was not always correct. Therefore, they emphasized the need to be ready to adapt their strategies quickly as new information becomes available. 
"I'll bet you that publicly available information has been filtered and modified to fit the government's propaganda... it would have been too late to be of any use... You have to know somebody in government... I only trust my family and close partners but my antennas [ears] are always up to catch news... who knows what we can catch?" (Founder of C1)

Our comparison of information gathered from the sampled firms with information we acquired from other sources such as industry reports, journal articles, and reports by international organizations revealed many inconsistencies. When managers were asked to explain these inconsistencies, almost all of them blamed poor information access due to censorship, reliance on informal information channels, and poor information management. Therefore, we must emphasize the importance of managers' perceptions, which can change rapidly when new information is available.

Uncertainty is a constant factor in the minds of the decision makers in our study. They always feel that they have too little correct information, which leads to a lack of confidence in the soundness of the judgments behind any given plan of action. Therefore, they need to obtain more information about the factors likely to affect their business by following regular procedures with sequential considerations of alternatives and a policy of reacting to feedback rather than forecasting the environment. As predicted by Cyert and March (1992), these firms avoid planning when their plans depend on predictions of uncertain future events and engage in emphasizing planning when their plans can be made self-fulfilling through some control device.

Vietnam is developing its institutions and trying different economic models to find the ones that fit, and its fast economic development is causing dramatic shifts in the market structure. This state of affairs requires firms to react quickly to changes to stay in the game. Furthermore, when institutions change, experience can be irrelevant in the new business environment. As such, they need to have broad knowledge of the current situation and be prepared for changes. Indeed, all the interviewed managers were quite vocal about flexibility being the key to success. They believe that conducting several concurrent experiments enables them to quickly react to changes.

"Textbooks teach us that we have to study markets, be focused and make systematic strategic planning to internationalize. These recommendations make little sense to us because our environment changes so often and so quickly that we just don't have enough time to do so. It's much more efficient to throw a fishing net [run simultaneous trials]". (Owner of C4)

On the other hand, Vietnam's underdeveloped financial system makes it impossible for the interviewed managers to implement certain strategies. For example, many SMEs wanted to become active in e-commerce before 2005, but it was almost impossible for them to receive credit card payments online unless they had a bank account abroad. Even now, e-commerce is not a feasible option for many SMEs because their managers do not have enough confidence of the security of transactions involving Vietnamese banks. However, with improvements to the banking system, these constraints are gradually disappearing and SMEs will soon have more and more strategic choices.

We also found that the perceived degree of internationalization in the industries in which the firms operate has a significant impact on the international development of the 
firms studied. Due to the limited access to quality international market information, most of the interviewed managers sense the degree of internationalization in an industry by evaluating the density of internationalizing Vietnamese businesses in that industry. The more they see similar Vietnamese SMEs internationalizing, the more they are motivated to follow suit. If they do decide to enter the international market, they are most likely to adopt the same internationalization modes as other SMEs they have seen.

"I saw many companies make good money by exporting cashews so we tried it too. The market was very hot. Everybody was doing that. Now many are going to Africa so we are planning to go there. In fact, some African customers have contacted us. It looks like a good destination now." (Managing director of C25)

This herding practice can create the wrong perception for other firms about internationalization opportunities, but only in the short term. Once these firms actually become active internationally, they will learn more about it and be able to judge for themselves whether this strategy is the right one for them. In light of this experience, they can then decide to continue or adapt or abandon their internationalization effort. As such, their strategy is not explicitly formulated in an a priori manner, but emerges gradually, even unintentionally, as managers make decisions one by one.

\section{Strategy dynamics}

Weak law enforcement leads businesses to rely on "private ordering," i.e., reliance on social norms and the use of non-government forces to resolve conflicts (Appold 2004). This state of affairs leads Vietnamese firms to do business by exploiting relationships that act as conduits for internationalization.

Despite banking and financial reforms, many private SMEs feel that obtaining investment capital from financial institutions is a kind of "mission impossible" because of the sector's overly complicated appraisal procedures and strict collateral requirements. As a result, managers need to rely on their personal networks to mobilize capital. This would mean that when a manager resigns from a firm, the firm will lose his ability to mobilize capital but will have to depend on the new manager's personal networks to mobilize capital.

Decision making in the firms studied is very informal and spontaneous. Managers do not rely on sophisticated processes partly because Vietnam's poor education system has failed to provide them with the necessary business knowledge and skills. A report published in 1998 by the Vietnamese Ministry of Education and Training - Summary and Evaluation of the Ten-year Reform of Education and Training (1986-1996)-emphasized that "there is a very weak relationship between universities and the business sector." The Ministry also reported in its "National Congress for Assessing the Quality of University Education," held on January 5, 2008, that "over $50 \%$ of university graduates must be retrained because their technical knowledge and skills do not meet the standards required by potential employers."

This state of affairs partly explains why managers' actions in the international arena appear to be guided by their perceptions and impulses to experiment with different modes, different countries, and different industries to find the best fit. As such, resource availability obviously determines the scale and scope of their experiments. Compared to private firms, state-run enterprises carry out more experiments 
and at larger scales because the government guarantees their existence, gives them preferential treatment, and covers their losses. In these firms, since survival and profit may not be critical, managerial goals play an important role in internationalization.

Interestingly, we found that the absence of the necessary resources does not deter either state-own firms or private firms from internationalizing if they desire to do so. When firms spot an opportunity or sense that industry pressure is great enough to necessitate internationalization, they will bide their time in that industry and exploit indirect modes while actively seeking solutions. If the inability to internationalize is internal (insufficient resources and capabilities), managers actively seek help. If the inability is the result of government policy, firms exploit indirect modes until the barrier is removed.

For example, before December 1998, it was almost impossible for private firms to obtain export quotas directly because the application procedures were cumbersome and costly. Even if they were successful in their application, private firms were only able to obtain small quota allocations. The firms that were able to export directly were often the ones that bought quotas from state-owned enterprises. Since this practice was considered illegal, they circumvented the law by having the state-owned firms subcontract quota items to private firms, with the output officially recorded as having originated from the state-owned firms. Private firms only began to export directly once the government had implemented measures such as auctioning export quotas to ensure that they would be allocated to firms that performed the best. Nevertheless, private firms still find it very difficult to get export quotas if they do not have "insiders" with strong connections to the Ministry of Trade and Industry.

Interaction of motivation, dynamic perception, and firm's capability

The development of a firm's internationalization strategy is a function of its objectives as well as internal and external factors. In our study, we found that the full life cycle of the internationalization strategy (conception, elaboration, decay, and death) varies within and across firms depending on how three factors discussed above interact with one another (Fig. 1).

Situation 1 is when the firm is the most motivated to internationalize but needs to experiment with different markets and entry modes within its capabilities to find the

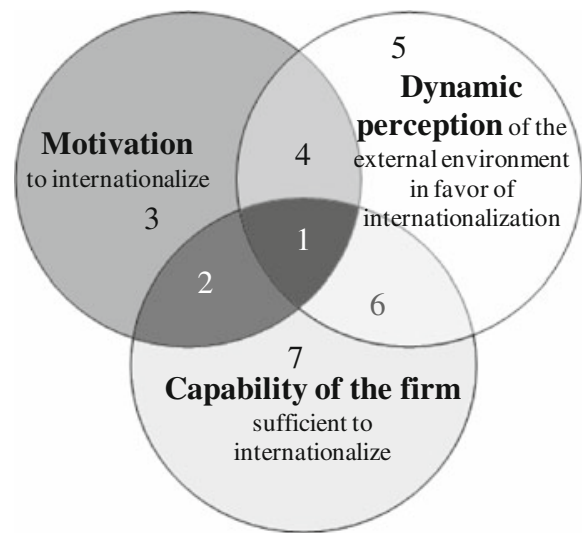

\section{Decision in each particular situation:}

1 : Internationalize by experimenting with different markets and entry modes

2: Internationalize by experimenting with different industries, markets, and entry modes

3: Explore opportunities in other industries and actively seek help

4: Exploit indirect modes and actively seek help

5: Opt out of internationalization

6: Opt out of internationalization

7: Opt out of internationalization

Fig. 1 Determinants of internationalization 
best fit. If the company's perception of the internationalization opportunities in a given industry is correct, then it is likely to succeed. Therefore, quality information is the key to developing winning internationalization strategies.

In situation 2, the firm internationalizes because it both wants and has the ability to do so, even though the managers see that industry pressure is light and the opportunity is limited. If there is no opportunity in this industry, the firm's managers will actively seek opportunities in another industry. It conducts experiments in each industry to improve its learning curve and to find strategies that work. For the firm to be able to do so, short-term profits may not be critical to survival. This is often the case with SOEs, whose financial standing is protected by the government.

In situation 3, the firm and/or its manager want to embark on internationalization. The firm, however, does not see any opportunity in its industry and is unable to internationalize. If this inability comes from within (i.e., it does not yet have the needed resources and capabilities to do so), the manager will actively seek partnerships and/or lobby government officials or anyone in power to help. The firm may even enter a new industry so long as doing so creates an opportunity for it to go international. If the inability is caused by the government's policy of designating certain SOEs to engage in import/export in certain industries, the firm exploits indirect modes such as selling exported goods to or buying imported goods from these designated SOEs. However, this strategy is temporary since the firm will jump to direct internationalization (situation 1 or situation 2) when this kind of barrier is removed.

In situation 4, the firm and/or its managers desire internationalization because the firm has spotted an opportunity or perceived the industry pressure to internationalize. However, the firm is unable to do so because of its inability to mobilize the needed resources and capabilities, and hence would choose to wait and seek for opportunities, while exploiting indirect modes. When given help either by the government or by people in the firm's networks, it will quickly move into the international market.

In situation 5, the firm and its managers have no desire to internationalize and do not have the necessary resources and capabilities to do so. It would therefore remain purely domestic in the given industry if the pressure to internationalize is perceived to be low. To be enticed to internationalize, the firm must be given encouragement and assistance from outside. In other words, the firm is reactive, and even when it decides to internationalize, it would do so with low managerial commitment.

In situation 6, the firm chooses to remain domestic in its industry. Although the firm has the capacity to internationalize, its managers are not interested in doing so. In this case, the managers will try to avoid or delay internationalization.

In situation 7, the firm remains a purely domestic operation in the particular industry. The firm's managers do not want their firm to internationalize and do not seek out foreign business opportunities or feel the pressure to go international. If the indifference is caused only by the mangers' failure to identify opportunities, public propaganda and the availability of the right information can quickly change their opinion. If the managers receive the right information, they will quickly change their attitude towards internationalization. In these cases, the availability of quality information and encouragement from seeing the successful experiences of other firms can have a significant impact. If the indifference comes from the manager's prejudice and low risk tolerance, the situation will remain the same for a long time. However, the firm may change its position when there is a change in the composition of the management board. 


\section{Emergent theoretical model}

The previous section shows the dynamic nature of the internationalization of SMEs in a fast changing environment. It highlights the fact that the dynamism is caused by factors unique to economies undergoing fast changes and which influence decision makers' desire, perception of external conditions, and use their firm's capabilities. The evaluation of the interaction of factors pertinent to these dimensions reveals a model of dynamic experimental internationalization shown in Fig. 2 and articulated as below.

\section{Theoretical construct}

Internationalization strategy development consists of conducting small-scale experiments that the firm can afford and in making the highest commitment to the strategy that best fits the environment while serving the internationalization objectives set by the firm or the manager.

Internationalization pattern (timing, market, product, operation mode) is dynamic and is contingent upon (1) internationalization motivation which is determined by managers' desire to meet their personal goals or organizational goals, (2) dynamic perception of the external environment which is determined by information available to the firm, and (3) the firm's dynamic capabilities which is determined by the composition of management board and the performance of previous strategies.

\section{Explanatory mechanisms}

1. SMEs in changing environment cannot rely on knowledge gained from past experience (i.e., experiential learning from the past) because past experiences can be irrelevant in the new business environment where institutions have changed. Instead, they need to have broad knowledge gained from currently on-going experience via experimentation in order to react quickly to changes.

2. Unstable institutions as well as constraints on SME, such as lack of managerial skills, international market knowledge, etc., lead these firms to focus on short-term strategies and to avoid longer term planning.

3. Lack of access to quality information due to censorship, propaganda, and weak infrastructure force people to make decisions based on perceptions and intuition. Knowing that the information used to make decisions can be of poor quality, decision

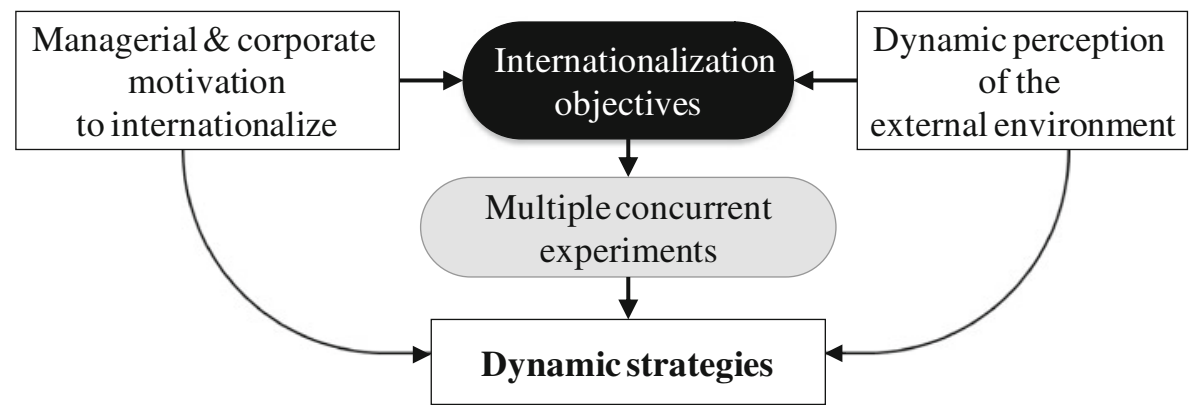

Fig. 2 Model of dynamic experiential internationalization 
makers are ready to adjust their strategies when new information arrives. On the other hand, this state of affairs also leads people to blame failure on bad luck and to attribute success to good luck. This makes it possible for managers to use their companies as vehicles to satisfy their personal interests.

4. State intervention in firms' business activities (particularly state-controlled enterprises) and corruption can create unexpected shifts that enable firms to internationalize or force them to change their international operations or even cause them to de-internationalize.

\section{Dynamism determinants}

1. Speed of institutional changes which determines the usefulness of past experience as well as preparation for changes.

2. Acquisition and quality of new information which influence decision makers' perception of the external environment and how they modify strategies when new information arrives.

3. Frequency of change in managerial structure, given that internationalization strategy is determined by internationalization objectives, which, in turn, are determined by the manager's desire to meet his/her personal goals or the firm's organizational goals

\section{Conclusions}

\section{Contribution to theory}

Like other knowledge-based models in the behavioral school, our model shares the same assumptions that decision makers and organizations are subject to (1) limited rationality, (2) certain lack of knowledge about alternative actions and their outcomes, (3) conflicting goals and aspirations, and (4) attempts at avoiding uncertainty, and argues that internationalization is determined by a firm's experience. However, the learning curve does not necessarily result in reduced risk or higher commitment. Rather, the knowledge acquired from concurrent experiments enables a firm to find strategies that allow it to best fit into its environment at a particular time and provide it with the best chance of meeting the goals of either the firm or its managers. Moreover, decision makers do not aim at strengthening the firms' network positions by internationalizing. Rather, success may depend on luck because of poor information, corruption, and state intervention. In addition, limited management capacities and the need for multiple-layer learning make it hard for decision makers to have a clear idea of their firm's position in the market and whether to improve it or protect it.

Secondly, our results strongly support Clercq et al. (2005) who stressed the importance of learning and perception. It is also in line with findings in Mainela and Puhakka's study in Poland (2009) that transition economies including Vietnam present a turbulent context that requires businesses to adopt an approach that resembles effectuation developed by Sarasvathy $(2001,2008)$. However, the internationalization of SMEs in a fast changing environment is not the same as the said effectuation process because decision makers in our study try many alternatives to 
serve only one goal (which could be set by either the firm or the manager). This study also supports Ahlstrom and Bruton's findings (2010) that rapid institutional shifts require firms to rapidly co-evolve with institutional changes in order to survive and prosper in their environment. At the same time, it gives further evidence to strengthen Shinkle et al.'s explanation (2013) for why pure strategies may be wrong for transition economy firms. It extends Schaumburg-Müller and Chuong's study (2009) by showing the mechanisms underlying why Vietnamese managers use dynamic approach to internationalization.

Thirdly, unlike existing contingency theories which only account for the potential influence of external factors, the dynamic experimental internationalization model developed in this study incorporates both internal and external factors into its explanatory matrix. At the same time, it synthesizes elements of other internationalization process theories in that it acknowledges the concurrent influence of managerial characteristics, firm characteristics, industry structure and attributes, socioeconomic infrastructure, and the interrelationships among these factors rather than considering each factor separately. It clearly demonstrates that the SME internationalization process is not determined by rational choices made with a view to obtaining optimum results. Rather, it is an experimental process undertaken by management which results in strategies for expansion, contraction, or hibernation, depending on the contingencies in emerging situations.

Fourthly, our model emphasizes the role of the decision makers and incorporates bounded rationality, decision-making biases and judgments by managers in the face of environmental uncertainty. This element has been neglected in research on managerial decision making in international business over the past 45 years (Aharoni et al. 2011), although researchers strongly argue that SME internationalization decision making is influenced by managerial cognition (Collinson and Houlden 2005; Fletcher et al. 2013). Our model reveals the rationality of decisions that appear irrational to outsiders and helps us understand why firms behave in certain ways. Whether firms increase or decrease their international commitment is explained by whether their managers judge that a particular strategy can help them meet their goals (which may or may not be consistent with organizational goals) rather than other strategies. As such, a change in managerial structure (in which the new managers have a whole new set of drives) or a change in the managerial perception of the context due to the arrival of new information can trigger changes in internationalization strategies. Our study highlights the fact that while firms make decisions based on their perception of external factors, this perception can yield a misguided view of reality because of information distortion by government censorship. However, as firms continuously experiment and search for information, their perception can change very quickly. Indeed, this process can accentuate the dynamism and velocity of strategic changes in the internationalization of SMEs in a fast changing environment.

Lastly, our findings note that internationalization is not necessarily aimed at creating values for the firm, but it can be a means for decision makers to meet their personal goals. This supports agency theory argument and George et al.'s findings (2005) about the role of ownership in top management's strategy formulation. We also discovered that decision makers are not necessarily entrepreneurs, who by definition are risk takers, opportunity pursuers, and innovators (Fisher and Koch 2008; Shefsky 1996). Therefore, internationalization may not be exclusively an 
international entrepreneurial process since it is influenced by factors such as the firm's internationalization objectives and ownership type (SOE or otherwise).

\section{Managerial implications}

The macro environment of an economy in transition requires SMEs to develop the ability to learn quickly through experimentation, to be very flexible to implement strategic and managerial changes quickly, and to solve problems creatively within the limits of their capabilities and resources in order to cope with an ever-changing environment. Therefore, managers of SMEs in these economies need to stay their course with clearly defined goals while remaining very flexible with regard to short-term objectives and ways to meet the goals in the long term. Furthermore, they have to find creative ways of solving all problems arising from contextual changes while accepting the inevitability of external changes and working with limited resources and capabilities.

The results of our study also suggest that if managers in a rapidly changing economy can improve the quality of their information acquisition and management, they can conduct better targeted experiments and thus optimize their effectiveness. Foreign companies doing business or planning to do business with SMEs in such an economy need to be aware that these SMEs are likely to change their strategies. However, if they can predict the type and direction of context changes, they can predict how the SMEs will behave when changes occur. In other words, foreign firms can have a significant competitive advantage if they understand the host country environment and are able to use their market and international knowledge, their experience, and their relationships to predict changes.

\section{Limitations of the study}

Although various measures were used to enhance the robustness of our research, its results are not without limitations. Like other qualitative research studies, it could suffer from problems related to generalizability and parsimony (Ragin 1994). Our research was not designed to measure across the population but to develop a theoretical model so we only achieved analytical generalization rather than statistical generalization (Yin 2011). Consequently, further research is necessary to test the propositions generated in this study. Another limitation is a possible bias from the retrospective nature of some of the qualitative data, such as the views of interviewees on the reasons for decisions made several years earlier. Although the use of multiple data sources and the iterative interview process might minimize this danger, it is nevertheless acknowledged that retrospective bias may not have been entirely eliminated. Finally, our study focuses on Vietnamese managers so we do not know the extent to which Vietnamese culture versus Vietnam's business environment influence how Vietnamese SME internationalize. We acknowledge the foregoing limitations. However, since the major goal of our research is to uncover new concepts which can be used to build a theoretical model and to generate a framework for subsequent testing, these limitations do not affect the integrity of our study.

Acknowledgments We would like to thank the three anonymous reviewers as well as the chief editor, Prof. Hamid Etemad, for their constructive comments during the review process which helped us improve the quality of this manuscript. 


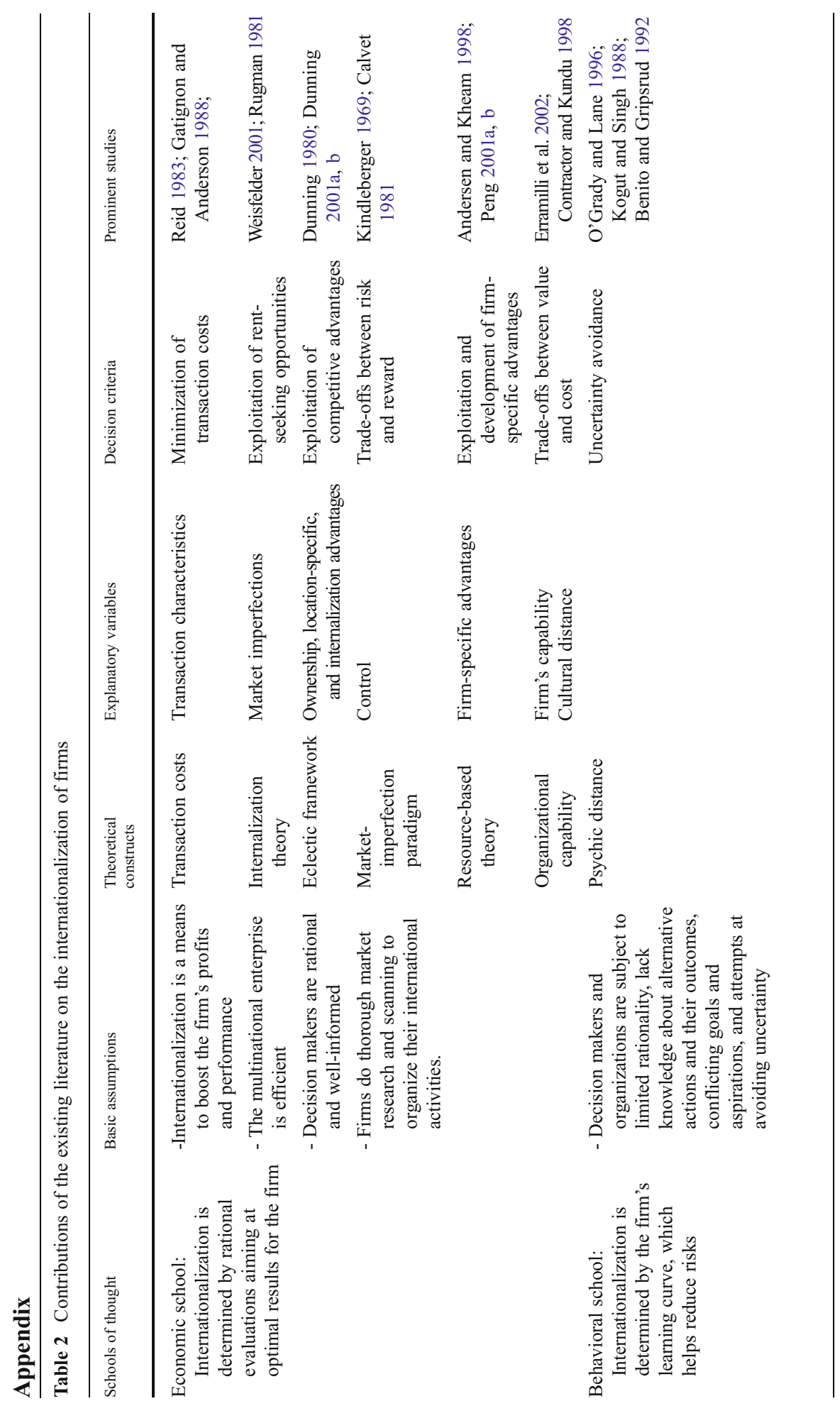




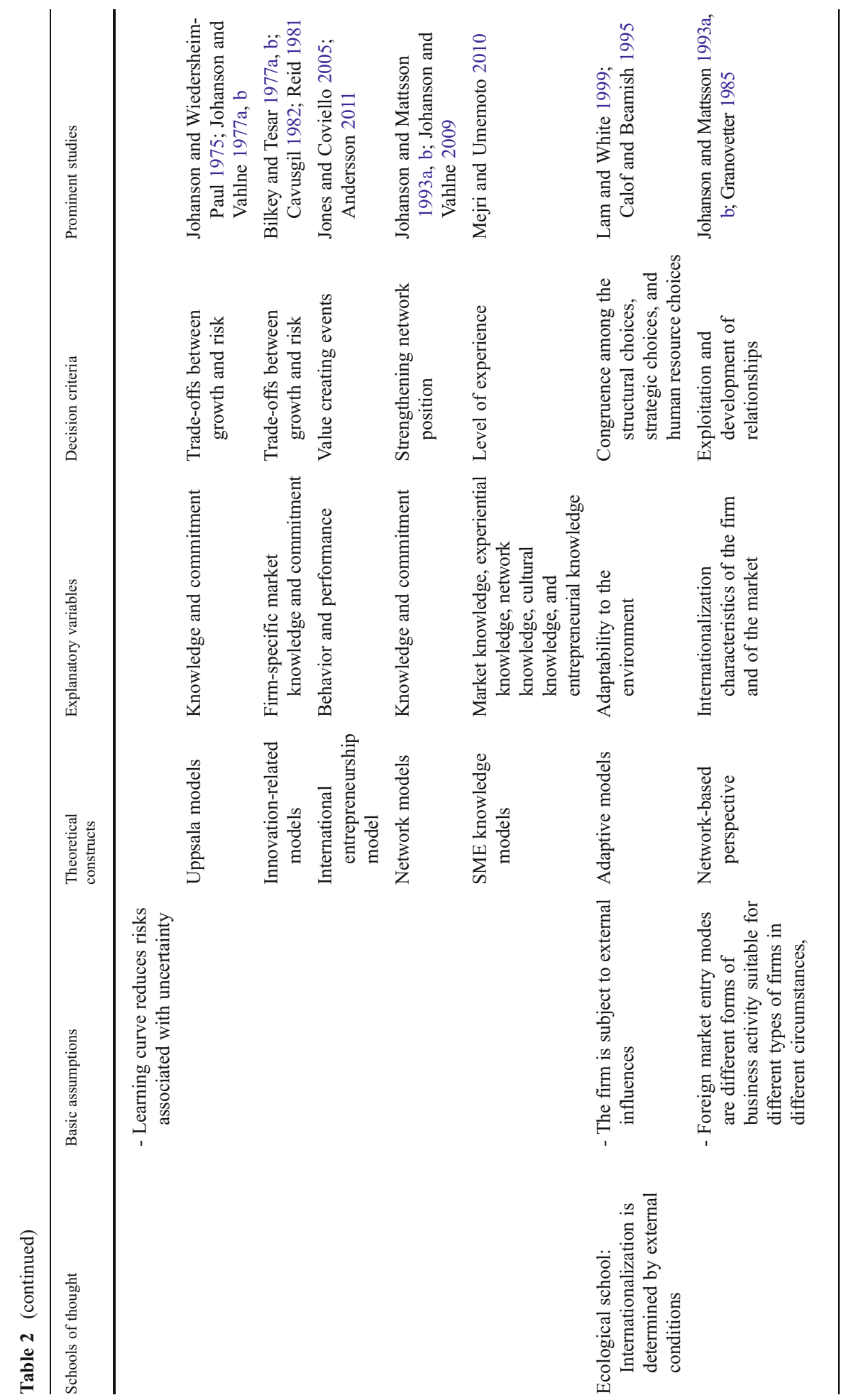




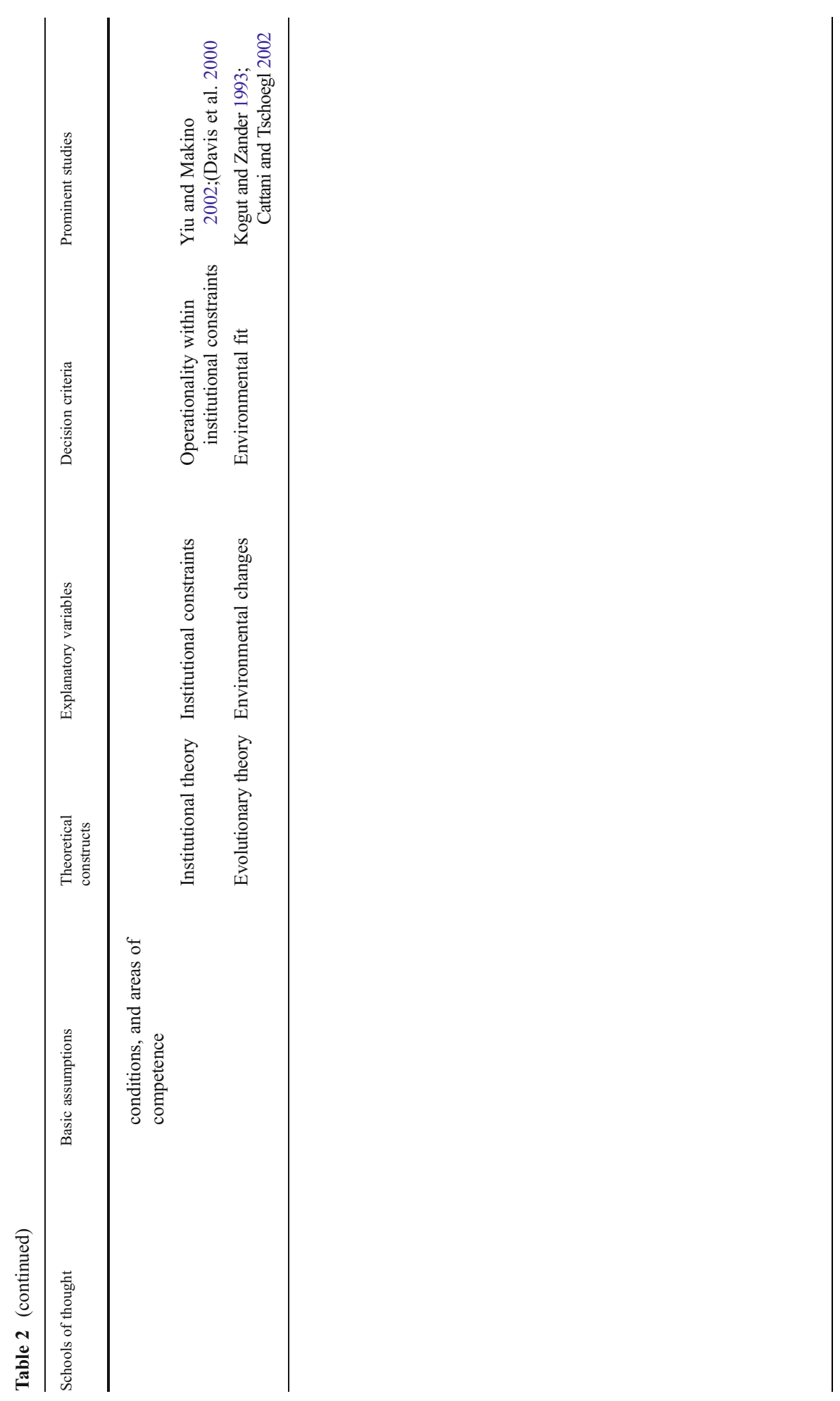




\section{References}

Aharoni Y (1966) The foreign investment decision process. Harvard University Press, Cambridge

Aharoni Y, Tihanyi L, Connelly BL (2011) Managerial decision-making in international business: a fortyfive-year retrospective. J World Bus 46(2): 135

Ahlstrom D, Bruton GD (2010) Rapid institutional shifts and the co-evolution of entrepreneurial firms in transition economies. Entrep Theory Pract 34(3):531-554

Andersen O (1993) On the internationalization process of firms: a critical analysis. J Int Bus Stud 24(2):209-231

Andersen O, Kheam LS (1998) Resource-based theory and international growth strategies: an exploratory study. Int Bus Rev 7(2):163-184

Andersson S (2011) International entrepreneurship, born globals and the theory of effectuation. J Small Bus Enterp Dev 18(3):627-643

Appold S (2004) Social embedding as a solution to a control problem: evidence from Vietnamese small business. In: The annual meeting of the American Sociological Association, San Francisco, CA

ASMED (2006) Small and medium enterprise development: 5 year plan 2006-2010. Agency for SME Development, Vietnam's Ministry of Planning and Investment, Hanoi, Vietnam

Barney JB, Wright M, Ketchen DJ Jr (2001) The resource-based view of the firm: ten years after 1991. J Manag 27(6):625-641

Benito GRG, Gripsrud G (1992) The expansion of foreign direct investments: discrete rational location choices or a cultural learning process? J Int Bus Stud 23(3):461-476

Benito GRG, Welch LS (1997) De-internationalization. Manag Int Rev 37(2):7-19

Benito GR, Petersen B, Welch LS (2009) Towards more realistic conceptualisations of foreign operation modes. J Int Bus Stud 40(9):1455-1470

Bilkey WJ, Tesar G (1977a) The export behavior of smaller Wisconsin manufacturing finns. J Int Bus Stud 8(1):93-98

Bilkey WJ, Tesar G (1977b) The export behavior of smaller Wisconsin manufacturing finns. J Int Bus Stud 8(1):93-98

Bjorkman I, Forsgren M (2000) Nordic international business research. Int Stud Manag Organ 30(1):6-25

Brouthers KD, Hennart J-F (2007) Boundaries of the firm: insights from international entry mode research. J Manag 33(3):395-425

Buckley PJ, Casson MC (2009) The internalisation theory of the multinational enterprise: a review of the progress of a research agenda after 30 years. J Int Bus Stud 40(9):1563-1580

Calof JL, Beamish PW (1995) Adapting to foreign markets: explaining internationalization. Int Bus Rev 4(2):115-131

Calvet AL (1981) A synthesis of foreign direct investment theories and of the multinational firm. J Int Bus Stud 12(1):43-59

Canabala A, White GO III (2008) Entry mode research: past and future. Int Bus Rev 17(3):267-284

Cattani G, Tschoegl AE (2002) An evolutionary view of internationalization: Chase Manhattan Bank, 1917 to 1996. The Wharton Financial Institutions Center, Philadelphia

Cavusgil ST (1982) Some observations on the relevance of critical variables for internationalization stages. In: Czinkota MR, Tesar G (eds) Export management: an international context. Praeger, New York

Cavusgil ST (1990) On the internationalization process of firms. In: Thorelli HB, Cavusgil ST (eds) International marketing strategy, 3rd edn. Pergamon Press, Elmsford, pp 147-159

Chen R, Cannice MV, Daniels JD (2001) Market entry and international technology transfer: a case analysis of ten U.S. high-tech firms in China and Southeast Asia. Adv Int Mark 11:133-155

Cheng J (2009) China, Malaysia scale back censorship; Vietnam steps it up. Condé Nast Digital. August 14, 2009 4:18 PM. http://arstechnica.com/web/news/2009/08/asian-censorship-roundup-two-steps-forward-one-step-back.ars Accessed 25 Aug 2010

Clercq DD, Sapienza HJ, Crijns H (2005) The internationalization of small and medium-sized firms. Small Bus Econ 24(4):409-419

Collinson S, Houlden J (2005) Decision-making and market orientation in the internationalization process of small and medium-sized enterprises. Manag Int Rev 45(4):413-436

Contractor FJ, Kundu SK (1998) Modal choice in a world of alliances: organizational forms in the international hotel sector. J Int Bus Stud 29(2):325-356

Country Profile: Vietnam (2007) OpenNet Initiative. http://opennet.net/research/profiles/vietnam. Accessed 25 Aug 2010

Cyert RM, March JG (1992) A behavioral theory of the firm. Blackwell Publishers, Cambridge 
Davidson WH (1983) Market similarity and market selection: implications for international marketing strategy. J Bus Res 11(4):439-456

Davis PS, Desai AB, Francis JD (2000) Mode of international entry: an isomorphism perspective. J Int Bus Stud 31(2):239-258

Denscombe M (1998) The good research guide for small-scale social research projects. Open University Press, Philadelphia

Dunning JH (1980) Toward an eclectic theory of international production. Some Empirical Tests 11(1):9-31

Dunning JH (2001a) The eclectic (OLI) paradigm of international production: past, present and future. Int J Econ Bus 8(2):173-190

Dunning JH (2001b) The eclectic (OLI) paradigm of international production: past, present and future. Int J Econ Bus 8(2):173-190

Easterby-Smith M, Thorpe R, Lowe A (1994) Management research: an introduction. Sage Publications, Thousand Oaks

Eisenhardt KM (1989a) Agency theory: an assessment and review. Acad Manag Rev 14(1):57-74

Eisenhardt KM (1989b) Building theories from case study research. Acad Manag Rev 14(4):532-550

EIU (2009) Country profile Vietnam 2009. Economist Intelligence Unit, New York

Erramilli MK, Agarwal S, Dev CS (2002) Choice between non-equity entry modes: an organizational capability perspective. J Int Bus Stud 33(2):223-242

Etemad H (2004) Internationalization of small and medium-sized enterprises: a grounded theoretical framework and an overview. Can J Adm Sci 21(1):1-21

Fina E, Rugman AM (1996) A test of internalization theory and internationalization theory: The Upjohn Company. Manag Int Rev 36(3):199-213

Fisher JL, Koch JV (2008) Born, not made: the entrepreneurial personality. Praeger Publishers, Westport

Fletcher M, Harris S, Richey Jr RG (2013) Internationalization knowledge: what, why, where and when? Journal of International Marketing (ja): 1-52

Gatignon H, Anderson E (1988) The multinational corporation's degree of control over foreign subsidiaries: an empirical test of a transaction cost explanation. J Law Econ Organ 4(2):305-336

George G, Wiklund J, Zahra SA (2005) Ownership and the internationalization of small firms. J Manag 31(2):210-233

Glaser BG, Strauss AL (1967) The discovery of grounded theory: strategies for qualitative research. Aldine, Chicago

Goulding C (2002) Grounded theory: a practical guide for management, business and market researchers. Sage Publications, Thousand Oaks

Granovetter M (1985) Economic action and social structure: the problem of embeddedness. Am J Sociol 91(3):481-510

Hadjikhani A, Hadjikhani AI, Thilenius P (2013) The internationalization process model: a proposed view of firms' regular incremental and irregular non-incremental behaviour. International Business Review

Handbook of Statistics 2006-2007 (2006) United Nations Conference on Trade and Development. http:// www.unctad.org. Accessed 1 Feb 2008

Hook RC Jr, Czinkota M (1988) Export activities and prospects of Hawaiian firms. Int Mark Rev 5(4):51-57

Huang Z, Brown A (1999) An analysis and classification of problems in small business. Int Small Bus J 18(1):73-85

Johanson J, Mattsson L-G (1993a) Internationalization in industrial system: a network approach. In: Buckley PJ, Ghauri PN (eds) The internationalization process of the firm: a reader. Academic Press, San Diego, pp 303-321

Johanson J, Mattsson L-G (1993b) Internationalization in industrial system: a network approach. In: Buckley PJ, Ghauri PN (eds) The internationalization process of the firm: a reader. Academic Press, San Diego

Johanson J, Vahlne J-E (1977a) The internationalization process of the firm-a model of knowledge development and increasing foreign market commitments. J Int Bus Stud 8(1):23-32

Johanson J, Vahlne J-E (1977b) The internationalization process of the firm - a model of knowledge development and increasing foreign market commitments. J Int Bus Stud 8(1):23-32

Johanson J, Vahlne J-E (2009) The Uppsala internationalization process model revisited: from liability of foreignness to liability of outsidership. J Int Bus Stud 40(9):1411-1431

Johanson J, Wiedersheim-Paul F (1975) The internationalization of the firm: four Swedish cases. J Manag Stud 12(3):305-322

Jones MV, Coviello NE (2005) Internationalisation: conceptualising an entrepreneurial process of behaviour in time. J Int Bus Stud 36(3):284-303

Kindleberger CP (1969) American business abroad: six lectures on direct investment. Yale University Press, New Haven 
Kogut B, Singh H (1988) The effect of national culture on the choice of entry mode. J Int Bus Stud 19(3):411-432

Kogut B, Zander U (1993) Knowledge of the firm and the evolutionary theory of the multinational corporation. J Int Bus Stud 24(4):625-645

Lam LW, White LP (1999) An adaptive choice model of the internationalization process. Int J Organ Anal $7(2): 105-134$

Lau H-F (1992) Internationalization, internalization, or a new theory for small low-technology multinational enterprise? Eur J Mark 26(10):17-31

Lau H-F (2003) Industry evolution and internationalization process of firms from a newly industrialized economy. J Bus Res 56(10):847-852

Lee W-Y, Brasch JJ (1978) The adoption of export as an innovative strategy. J Int Bus Stud 9(1):85-94

Mainela T, Puhakka V (2009) Organising new business in a turbulent context: opportunity discovery and effectuation for IJV development in transition markets. J Int Entrep 7(2):111-134

M nh NĐ (2008) Resolution No. 21/NQ-TW of the 6th Communist Party Congress No.10 [Ngh quy t 21-NQ/ TW $\mathrm{c}$ a Ban Ch p hành Trung ương Đ ng C ng s n Vi t Nam khóa X]. Vietnam Communist party, Hanoi, VN

Manolovaa TS, Manevb IM, Gyoshev BS (2010) In good company: the role of personal and inter-firm networks for new-venture internationalization in a transition economy. J World Bus 45(3):257-265

Masurel E, Smit PH (2000) Planning behavior of small firms in central Vietnam. J Small Bus Manag 38(2):95-102

Mejri K, Umemoto K (2010a) Small- and medium-sized enterprise internationalization: towards the knowledge-based model. J Int Entrep 8(2):156-167

Mejri K, Umemoto K (2010b) Small- and medium-sized enterprise internationalization: towards the knowledge-based model. J Int Entrep 8(2):156-167

Nee V (1992) Organizational dynamics of market transition: hybrid forms, property rights, and mixed economy in China. Adm Sci Q 37(1):1-27

O’Grady S, Lane HW (1996) The psychic distance paradox. J Int Bus Stud 27(2):309-333

Oviatt BM, McDougall PP (1994) Toward a theory of international new venture. J Int Bus Stud 25(1):45-64

Oviatt BM, McDougall PP (1997) Challenges for internationalization process theory: the case of international new ventures. Manag Int Rev 37(2):85-99

Papadopoulos N (1988) Inventory, taxonomy and assessment of methods for international market selection. Int Mark Rev 5(3):38-51

Patton MQ (2002) Qualitative research \& evaluation methods. Sage Publications, Thousand Oaks

Peng MW (2000) Business strategies in transition economies. Sage, Thousand Oaks

Peng MW (2001a) The resource-based view and international business. J Manag 27(6):803-829

Peng MW (2001b) The resource-based view and international business. J Manag 27(6):803-829

Peng MW, Heath PS (1996) The growth of the firm in planned economies in transition: institutions, organizations, and strategic choice. Acad Manag Rev 21(2):492-528

Penrose ET (1959) The theory of the growth of the firm. Wiley, New York

Perren L, Ram M (2004) Case-study method in small business and entrepreneurial research: mapping boundaries and perspectives. Int Small Bus J 22(1):83-101

Pisani N (2009) International management research: investigating its recent diffusion in top management journals. J Manag 35(2):199-218

Praag CMV, Ophem HV (1995) Determinants of willingness and opportunity to start as an entrepreneur. Kyklos 48(4):513-540

Ragin CC (1994) Constructing social research. Pine Forge Press, Thousand Oaks

Reid SD (1981) The decision-maker and export entry and expansion. J Int Bus Stud 12(2):101-112

Reid S (1983) Firm internationalization, transaction costs and strategic choice. Int Mark Rev 1(2):44-56

Rugman AM (1981) Inside the multinationals: the economics of internal markets. Croom Helm, London

Ruzzier M, Hisrich RD, Antoncic B (2006) SME internationalization research: past, present, and future. J Small Bus Enterp Dev 13(4):476-497

Sarasvathy SD (2001) Causation and effectuation: toward a theoretical shift from economic inevitability to entrepreneurial contingency. Acad Manag Rev 26(2):243-263

Sarasvathy SD (2008) Effectuation: elements of entrepreneurial expertise. Edward Elgar Publishing, Inc., Northampton

Schaumburg-Müller H, Chuong PH (2009) The new Asian dragon: internationalization of firms in Vietnam. Copenhagen Business School Press, Copenhagen

Shefsky LE (1996) Entrepreneurs are made not born. Glencoe/McGraw-Hill, New York

Shinkle GA, Kriauciunas AP, Hundley G (2013) Why pure strategies may be wrong for transition economy firms. Strategic Management Journal 
Statistical data [Số liệu thống kê] (2007) General Statistics Office of Vietnam. http://www.gso.gov.vn. Accessed Jan 5

Strauss A, Corbin J (1998) Basics of qualitative research. Sage Publications, Thousand Oaks

Tashakkori A, Teddlie C (1998) Mixed methodology: combining qualitative and quantitative approaches. Sage Publications, Thousand Oaks

Thai MTT (2008) The internationalization of vietnamese small- and medium-sized enterprises. University of St. Gallen, St. Gallen

Thai MTT, Chong LC (2008) Born-global: the case of four Vietnamese SMEs. J Int Entrep 6(2):72-100

Tirole J (1988) The theory of firm. In: Tirole J (ed) The theory of industrial organization. MIT Press, Cambridge, pp 15-60

Transparency International (2010) Corruption Perceptions Index Transparency International. http:// www.transparency.org/policy_research/surveys_indices/cpi/2010. Accessed 10 Sept 2011

Vahlne J-E, Johanson J (2013) The Uppsala model on evolution of the multinational business enterprise - from internalization to coordination of networks. Int Mark Rev 30(3):189-210

Vo DL (2004) Vietnam economic renovation along socialist-oriented market economy. In: International Policy Conference on Transition Economies, Hanoi, Vietnam. Country Papers Series 11. United Nations Development Programme

Weisfelder CJ (2001) Internationalization and the multinational enterprise: development of a research tradition. Adv Int Mark 11:13-46

Welch C, Paavilainen-Mäntymäki E (2013) Putting process (back) In: Research on the internationalization process of the firm. International Journal of Management Reviews

Werner S (2002) Recent developments in international management research: a review of 20 top management journals. J Manag 28(3):277-355

Wright M, Westhead P, Ucbasaran D (2007) Internationalization of small and medium-sized enterprises (SMEs) and international entrepreneurship: a critique and policy implications. Reg Stud 41(7):10131030

Yin RK (2003) Case study research: design and methods. Sage Publications, Thousand Oaks

Yin RK (2011) Qualitative research from start to finish. The Guilford Press, New York

Yiu D, Makino S (2002) The choice between joint venture and wholly owned subsidiary: an institutional perspective. Organ Sci 13(6):667-683

Zafarullah M, Ali M, Young S (1998) The internationalization of the small firm in developing countries: exploratory research from Pakistan. J Glob Mark 11(3):21-40 